\title{
Sequence of hydrographic changes in NW Mediterranean deep water due to the exceptional winter of 2005
}

\author{
JORDI FONT, PERE PUIG, JORDI SALAT, ALBERT PALANQUES \\ and MIKHAIL EMELIANOV \\ Institut de Ciències del Mar CSIC, Passeig Marítim de la Barceloneta 37-49, 08003 Barcelona, Spain. \\ E-mail: jfont@icm.csic.es
}

\begin{abstract}
SUMMARY: Time series measurements at a mooring site on the deep slope of the NW Mediterranean from October 2003 to July 2005 revealed the sequence of effects of the anomalously dry, markedly cold, and very windy winter of 2005 in deep water thermohaline properties. At the end of January, a dense water mass that was warmer and saltier than usual reached the deep slope mooring site. Almost simultaneously, the start of deep dense shelf water cascading episodes was observed in the Gulf of Lions' submarine canyons. 30 days later, colder, fresher and even denser waters reached the mooring, with a 5-day delay from an intensification of the Gulf of Lions' cascading. The signature of these waters was detected for 35 days, and by late spring 2005 a new stable water mass situation was reached, with higher thermohaline values than those that characterised the deep layer from October 2003 to January 2005.
\end{abstract}

Keywords: dense water formation, cascading, submarine canyon, deep mooring, northwestern Mediterranean.

RESUMEN: SECUENCIA DE CAMBIOS HIDROGRÁFICOS EN El AGUA PROFUNDA DEL MEDITERRÁNEO NOROCCIDENTAL DURANTE EL EXCEPCIONAL INVIERNO DE 2005. - Una serie temporal de datos registrados en un anclaje en la parte profunda del talud continental del Mediterráneo noroccidental desde octubre de 2003 a julio de 2005 muestra la secuencia de los efectos del invierno de 2005, anómalamente seco, destacadamente frío y muy ventoso. A finales de enero una masa de agua densa, más caliente y salada de lo habitual, llegó al anclaje del talud profundo. Casi simultáneamente se observó en los cañones del Golfo de León el inicio de episodios de hundimiento profundo de agua densa de plataforma en forma de cascada. Al cabo de 30 días, 5 días después de intensificarse el hundimiento en cascada en el Golfo de León , aguas más frías, menos saladas, y todavía más densas, alcanzaron el anclaje y permanecieron allí durante 35 días. A finales de la primavera de 2005 se alcanzó un nuevo estado estacionario con valores de temperatura y salinidad más elevados que los característicos de la capa profunda desde octubre de 2003 hasta enero de 2005.

Palabras clave: formación de agua densa, hundimiento en cascada, cañón submarino, anclaje profundo, Mediterráneo noroccidental.

\section{INTRODUCTION}

The dense Western Mediterranean Deep Water (WMDW, see https: //www.ciesm.org/catalog/ WaterMassAcronyms.pdf for all the water masses referred to in the paper) is formed at open sea off the Gulf of Lions (NW Mediterranean) in a typical winter convection process around $42^{\circ} \mathrm{N} 5^{\circ} \mathrm{E}$
(MEDOC area) forced by heat losses and evaporation, caused by cold and dry northerly/northwesterly winds (Tramuntana and Mistral). This process involves intermediate water masses, mostly Levantine Intermediate Water (LIW), and presumably Tyrrhenian Deep Water (TDW). After its formation WMDW spreads to fill the entire western basin below $1000 \mathrm{~m}$ (MEDOC Group, 1970; 
Schott and Leaman, 1991). Around the MEDOC area, where surface water is typically less salty, and preferably on its $\mathrm{N}$ and $\mathrm{W}$ sides, a Western Mediterranean Intermediate Water (WIW) is formed under the effect of the same winds (Salat and Font, 1987). The WIW resulting from this second open sea mechanism is fresher and colder than WMDW, because its formation involves more recent Atlantic Water (AW) brought by the Northern Current instead of LIW or TDW, as they are located below the convection limit or offshore. The relatively cold WIW, with a strong interannual variability in its formation, remains below the fresher surface AW and above the LIW layer, and is brought to the southwest along the continental slope by the general circulation.

In addition to open sea deep and intermediate offshore convection processes, over the wide shelf of the Gulf of Lions northerlies also induce cooling, salinification and mixing of the low salinity coastal waters (influenced by river discharges, mainly of the Rhône). These eventually become denser than the surrounding waters and sink (Fieux, 1974). After travelling on the shelf bottom, they flow down the continental slope and cascade, mainly through submarine canyons until they reach their equilibrium (neutral density contrast), typically at 150-200 m (Durrieu de Madron et al., 2005), contributing to the WIW body (DufauJulliand et al., 2004). During some severe winters these cascading waters can become dense enough to reach deeper layers, as in winter 1999, when waters generated over the shelf were traced down to $1000 \mathrm{~m}$ together with intense downslope velocities (Bethoux et al., 2002).

In autumn and winter 2004-05 precipitation on the NW Mediterranean catchment area was very scarce, with the lowest absolute values ever recorded at many of the meteorological stations. Moreover, from 25 January to 10 March, 2005, air temperatures around the Gulf of Lions were lower, especially daily maxima, than the climatological average, and northerlies were strong and persistent (e.g. MétéoFrance records). The NCEP (US National Centres for Environmental Prediction) heat flux analysis for the Gulf of Lions indicated the highest value since 1948: $70 \%$ above the winter average (López-Jurado et al., 2005). Under these conditions, dense water formation in the Gulf of Lions' region was intensified and a major episode of deep dense shelf water cascading- even stronger than the 1999 one-occurred (Canals et al., 2006).

Several scientific teams and hydrographic services of Mediterranean countries are committed to tracking long term changes in deep water characteristics (Theocharis et al., 2003), within the HydroChanges pilot programme of the International Commission for the Scientific Exploration of the Mediterranean Sea (http:// www.ciesm.org/marine/programs/hydrochanges.htm; CIESM, 2002). As part of this programme, a series of deep moorings equipped with an autonomous CTD and sometimes a current meter are being set in place close to the seabed. Since October 2003 the Institut de Ciències del Mar of Barcelona (ICM) has maintained one of these moored stations (hereinafter named HC-ICM), located on the deep NW Mediterranean continental slope. This paper describes the temporal variability of the measurements recorded by this mooring, and analyses the sequence of events during the severe winter 2005 that affected the thermohaline properties of the NW Mediterranean deep water.

\section{TIME SERIES DATA}

The HC-ICM deep slope mooring was deployed at $1890 \mathrm{~m}$ depth off the Catalan coast $\left(41^{\circ} 28^{\prime} \mathrm{N}\right.$, $\left.3^{\circ} 40.4^{\prime} \mathrm{E}\right)$ south of the Palamós submarine canyon (Fig. 1). This location was chosen because it was previously used in 1993-94 for a study related to the spreading of the deep water formed in the NW Mediterranean (Send et al., 1996). The mooring was equipped with a SeaBird 37 model (SBE37) CTD recorder at $15 \mathrm{~m}$ above the bottom (hereinafter mab), and an Aanderaa RCM8 mechanical current meter at 11 mab. In a maintenance operation in July 2005 the mooring was recovered and redeployed with new instruments of the same characteristics. A post cruise calibration indicated that the SBE37 sensors had drifted by $0.0013^{\circ} \mathrm{C}$ in temperature and $0.00062 \mathrm{~S} / \mathrm{m}$ in conductivity during the 21 months of deployment.

In the same observational period, in the framework of the EU-NA EuroStrataform project, several moorings were deployed in the Gulf of Lions' submarine canyons. During the winter of 2003-04 seven canyon heads were instrumented with near-bottom (5 mab) Aanderaa RCM9 Doppler current meters equipped with temperature, conductivity, pressure and turbidity sensors deployed at $300 \mathrm{~m}$ depth (see Palanques et al., 

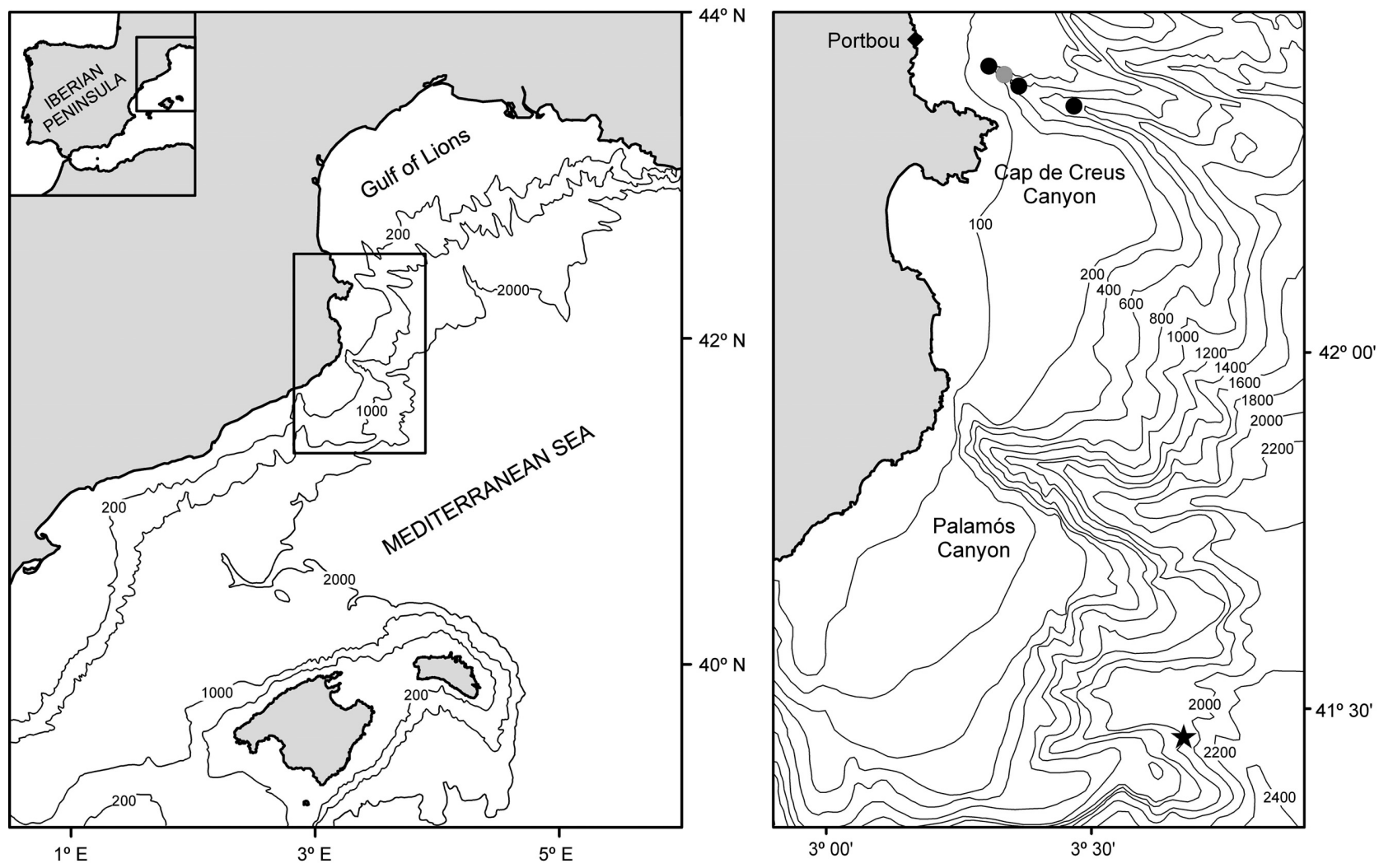

FIG. 1. - Northwestern Mediterranean area, including the Gulf of Lions and Catalan continental slopes indented by several submarine canyons (left). Location of the Portbou meteorological station (black diamond), the moorings deployed in the Cap de Creus Canyon in 2003-04 (grey dot) and 2004-05 (black dots), and the HC-ICM mooring site (star) in the deep slope south of the Palamós Canyon.

2006 for details), and during the winter of 2004-05 three moorings equipped with the same type of current meters, placed at 5 mab, were deployed along the Cap de Creus Canyon axis at 200, 500 and $750 \mathrm{~m}$ depth (see Canals et al., 2006 for details) (Fig. 1). For the purpose of this paper, only the records from the Cap de Creus Canyon are used.

Atmospheric conditions during the study period were obtained from the automatic meteorological station of Portbou, located at $191 \mathrm{~m}$ above sea level at the southwestern limit of the Gulf of Lions' area (Fig. 1). This station, maintained by the Catalan Meteorological Service, provided half-hourly values of wind speed and direction, air temperature and air relative humidity.

\section{RESULTS}

The Portbou station is usually affected by the strong winds that trigger the dense water formation, although due to its location at the edge of the Gulf of Lions it can underestimate the magnitude of some northerly events affecting the open sea area. This meteorological time series shows that in winter 2004-05 winds were particularly intense (daily means near to or above $20 \mathrm{~m} / \mathrm{s}$ ) for several consecutive days in November 2004 and especially in late January, February and early March 2005 (Fig. 2a). These windy periods coincided with relative humidity lower than average (Fig. 2b), a couple of marked air temperature minima events (less than $0^{\circ} \mathrm{C}$ ) (Fig. 2c) and daily maxima below $10^{\circ} \mathrm{C}$ for 30 consecutive days.

The results obtained during the 2003-04 and 2004-05 winter deployments in the Cap de Creus submarine canyon identified the presence of dense shelf water cascading events in the study area (Palanques et al., 2006; Canals et al., 2006). These cascading events were characterised by decreases in water temperature and increases in current speed (up to $80 \mathrm{~cm} / \mathrm{s}$ ) (Fig. 2d and 2e). During the winter of 2003-04 several single events that lasted for few days occurred from January to May, whereas during the winter of 2004-05 the lower air temperatures, the more persistent northerly cold and dry winds, and the reduction of river discharges (not shown) contributed to a dramatic 


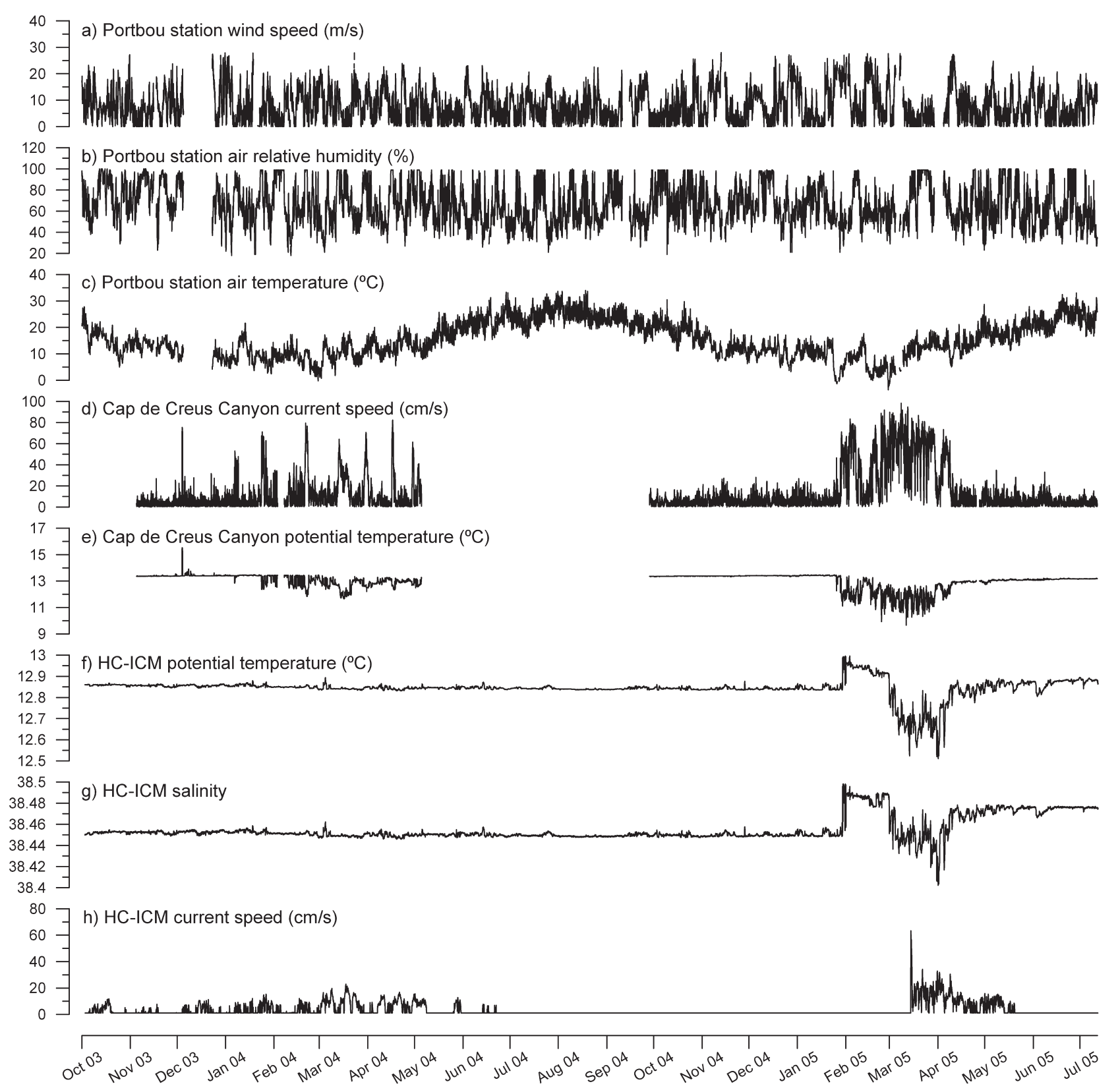

FIG. 2. - Time series from October 2003 to July 2005 of a) wind speed, b) relative humidity, and c) air temperature at the Portbou meteorological station; d) Current speed, and e) potential temperature at $300 \mathrm{~m}$ (winter 2003-04) and $500 \mathrm{~m}$ (winter 2004-05) along the Cap de Creus Canyon axis, $5 \mathrm{~m}$ above the bottom; f) potential temperature, g) salinity, and h) current speed at the HC-ICM mooring, located off the Catalan coast at $1890 \mathrm{~m}$ depth.

decrease in the buoyancy of the coastal waters, enhancing the intensity of the shelf water cascading mechanism. Under these weather conditions, cascading in the Cap de Creus Canyon began in late December 2004, earlier than in the preceding year. During the first events, this process only affected the canyon head (200 $\mathrm{m}$ depth), but in late January 2005 a major cascading event reached a depth of $750 \mathrm{~m}$. From late February to late March, cascading at $750 \mathrm{~m}$ depth occurred uninterrupted- ly, maintaining cold temperatures and downcanyon steady currents between 40 and $80 \mathrm{~cm} / \mathrm{s}$, showing periodic fluctuations that lasted for 3-6 days (Canals et al., 2006).

The time series of data recorded at the HC-ICM station indicates a clear difference between the winters of 2004 and 2005 (Fig. 2f and 2g). The potential temperature $\left(12.84-12.86^{\circ} \mathrm{C}\right)$ and salinity (38.45-38.46) values were almost unchanged from October 2003 to the end of January 2005, indicat- 
ing a stable water mass with typical WMDW characteristics $\left(\theta=12.8-12.9^{\circ} \mathrm{C}, \mathrm{S}=38.43-38.46\right.$, and $\sigma_{\theta}=29.09-29.10 \mathrm{~kg} / \mathrm{m}^{3}$ ). However, from January 2005 , simultaneously with the initiation of the deep cascading process in the Cap de Creus Canyon, $\theta$ and $\mathrm{S}$ increased rapidly to $12.99^{\circ} \mathrm{C}$ and 38.50 respectively, and then fluctuated for one month between 12.90 and $12.95^{\circ} \mathrm{C}$ and around $38.49\left(\sigma_{\theta}=\right.$ $\left.29.11 \mathrm{~kg} / \mathrm{m}^{3}\right)$. By early March potential temperature and salinity suddenly decreased by more than $0.2^{\circ} \mathrm{C}$ and 0.04 respectively, and remained for one month in a range of low values (with peaks down to $12.51^{\circ} \mathrm{C}$ and 38.41 ), followed by a gradual increase until they reached quite steady values of $12.88^{\circ} \mathrm{C}$ and $38.48\left(\sigma_{\theta}=29.117 \mathrm{~kg} / \mathrm{m}^{3}\right)$ when the mooring was recovered in July 2005.

The HC-ICM current meter record during the first part of the deployment showed very low speed values with some increases for short periods, reaching more than $10 \mathrm{~cm} / \mathrm{s}$ by mid-December 2003 and more than $20 \mathrm{~cm} / \mathrm{s}$ during the second half of March 2004. After lower peaks in May and June, the speed remained almost below the instrument threshold for the summer and autumn of 2004. In mid-March 2005 the speed peaked suddenly (with values above $60 \mathrm{~cm} / \mathrm{s}$ ), a few days after the temperature and salinity dropped and coinciding with the episode of maximum density values, maintained peak velocities of around $20-30 \mathrm{~cm} / \mathrm{s}$ until mid-April, then dropped to around $15 \mathrm{~cm} / \mathrm{s}$ and returned to the minimum values during the second half of May (Fig. 2h). The mooring was situated on a narrow submarine crest oriented WSW-ENE, so the local current direction was strongly influenced by the topography with continuous changes, but with a dominant SSW component, following the large-scale alongslope direction and hence indicating that the deep current was coming from the Gulf of Lions slope area. After the peak velocity in March 2005, the direction was reoriented towards SSE (Fig. 3), indicating that the flow was still predominantly oriented along the isobaths, but had a significant offshore component.

\section{DISCUSSION}

Previous CTD and current meter records in the HC-ICM mooring location in winter 1993-94 had indicated a cold temperature anomaly (less than $0.02^{\circ} \mathrm{C}$ ) in March 1994 related to the triggering of dense water formation in the Gulf of Lions, with no impact on the current regime at the foot of the con-

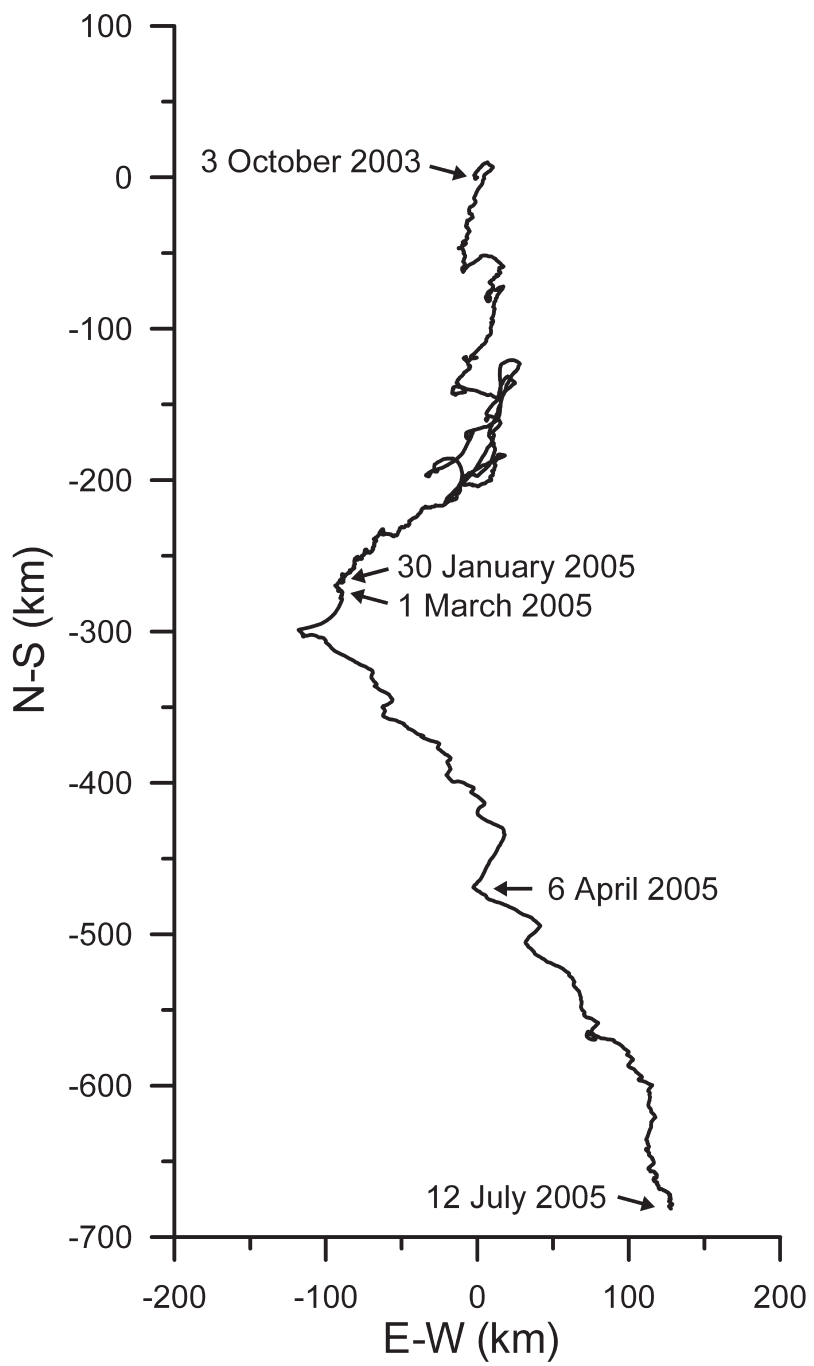

FIG. 3. - Progressive vector diagram from the data measured by the current meter deployed at the HC-ICM mooring site from October 2003 to July 2005. The transitions between the different regimes are marked with the corresponding dates. Note the predominant SSW current direction previous to the potential temperature and salinity anomalies, the low current velocities observed during the arrival of warmer and saltier waters, and the change towards a predominant SSE current direction (i.e. offshore) during the arrival of dense cold and less saline waters and after the "new" steady potential temperature and salinity values had been reached.

tinental slope (Send et al., 1996). The signals recorded in 2005 are much more dramatic, indicating some very special events related to the particular conditions of the exceptional 2004-05 winterperhaps in addition to other internal changes in the western Mediterranean deep water characteristics.

The sequence of potential temperature and salinity records at HC-ICM indicates that, before this exceptional winter, the location was occupied by WMDW circulating along the lower slope. The sudden irruptions of warmer and saltier water (off the standard WMDW range) on January 30 and of 
colder and fresher water on March 1 (Fig. 2f and $2 \mathrm{~g}$ ) preceded in time the CTD observations, made from mid-March, of a strong change in the thermohaline structure of deep layers in the NW Mediterranean with respect to previous years reported by López-Jurado et al. (2005) (see their Fig. 3), Salat et al. (2006) and Schröder et al. (2006) (their Fig. 2). This change was characterised by the uplift of the typical $\sigma_{\theta}=29.10 \mathrm{~kg} / \mathrm{m}^{3}$ isopycnal and the intrusion of waters below 1500 $\mathrm{m}$, presumably the new $2005 \mathrm{WMDW}$, forming a thick layer warmer and saltier than the typical WMDW. Moreover, below this layer and down to the bottom a less saline and colder water mass was found by these authors. Our HC-ICM time series records provide information about the sequence and timing of some of the processes that may have caused such potential temperature and salinity anomalies.

The 2005 winter convection in the NW Mediterranean was more intense than average (López-Jurado et al., 2005) and extended over an unusually large area (Salat et al., 2006). Moreover, the mixed LIW-TDW was saltier and warmer than in preceding years (Schröder et al., 2006), which was attributed to the accumulation of heat and salt in the NW Mediterranean at intermediate levels during the previous years, after the effects of the Eastern Mediterranean Transient (EMT, a dramatic change in the formation site and deep water mass characteristics in the eastern Mediterranean during the late 1980s and early 1990s, see e.g. Roether et al., 1996; Klein et al., 1999) reached the western basin, as tracked in the Sicily channel by increased $\theta$ and $\mathrm{S}$ maxima (Astraldi et al., 2002). In fact, Millot (2005) proposed that some observed changes in the western Mediterranean deep water masses are due to the presence of modified eastern waters brought to the western basin after the EMT. This would have occurred due to the modification of the LIW and especially the TDW thermohaline characteristics. Actual changes have been observed in the Mediterranean outflow at Gibraltar (Millot et al., 2006).

In 2005 then, WMDW was formed close to the continental slope (due to the larger extension of the open-sea convection area), where the LIW core is flowing as a vein (García-Ladona et al., 1996), and as a consequence the process involved water with a remarkably higher content of heat and salt than in previous years (both LIW and TDW). The January
30 irruption of warmer and saltier water occurred six days after the first strong (daily mean above $20 \mathrm{~m} / \mathrm{s}$ ) and cold (daily maximum below $10^{\circ} \mathrm{C}$ ) wind event was recorded at the Portbou meteorological station. This irruption was also concurrent with the start of the first cascading event detected at $750 \mathrm{~m}$ in the Cap de Creus Canyon. We can thus deduce that the conditions were adequate for the simultaneous triggering of offshore convection and shelf water cascading in the region (Fig. 4). We can assume then that the late January changes observed in HC-ICM would correspond to the arrival of offshore (i.e. open-sea) dense water with a larger contribution of very saline and warm LIW and TDW than usual.

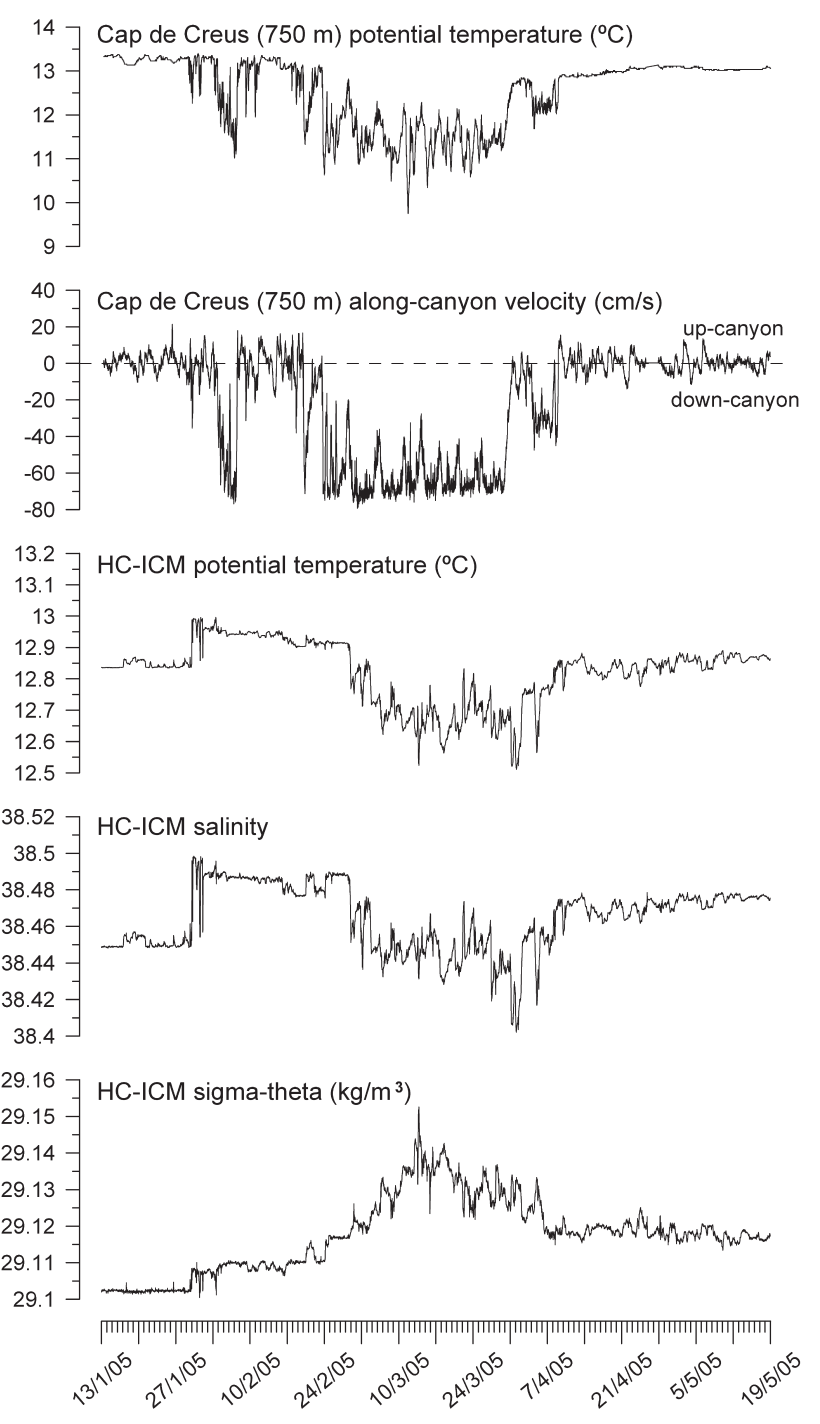

Fig. 4. - Time series of the potential temperature and along-canyon current component at $750 \mathrm{~m}$ along the Cap de Creus Canyon axis, together with the potential temperature, salinity and potential density records at the HC-ICM mooring, during the intense dense water formation events in winter 2005. 
The sustained high temperature and salinity values in the records suggest that this period lasted for almost a month. On March 1, the strong decrease in both temperature and salinity point to the presence of dense shelf waters as a main component of the water mass reaching the mooring site. Actually, measurements at $750 \mathrm{~m}$ depth within the Cap de Creus Canyon indicate that cascading waters began to flow down-canyon uninterruptedly from February 24 (Fig. 4). This delay of 5 days can be explained by the time that the cascading waters would need to travel from one site to the other. However, it is also likely that the cascading effect we observed had a contribution of local origin, from the relatively wide shelf south of Cap de Creus (Fig. 1). The high HC-ICM current meter speed in this period (Fig. 2h) corresponds to a flow that displays a persistent downslope component. The fact that these high currents were detected few days later than the local drop in temperature and salinity can be attributed, as has been shown on other occasions, to the blocking of the current meter rotor by adhered particles, which only cleared when the speed was high enough $(\sim 60 \mathrm{~cm} / \mathrm{s})$, coinciding with a burst of the most dense water recorded by the CTD. These waters that cascade from the shelf were detected in the mooring for more than one month, until April 2005, and reached a $\sigma_{\theta}$ peak of more than 29.15 $\mathrm{kg} / \mathrm{m}^{3}$. They lasted for almost the same period as the continuous Cap de Creus cascading, which stopped on March 30 (Fig. 4).

Our deep records also indicate that when the extraordinary cascading event finished, the densest cold and less saline water started to be replaced smoothly by the newly formed deep waters present in the offshore deep basin, until they stabilised at around $12.88^{\circ} \mathrm{C}, 38.48$, and $29.12 \mathrm{~kg} / \mathrm{m}^{3}$ (Fig. 4). This new deep water was warmer and saltier, and markedly denser than the previous typical WMDW, in agreement with the positive $\theta / S$ anomaly found after winter 2005 in the deep CTD casts mentioned above (see Figs. 3c and 3d in López-Jurado et al., 2005). The fact that the final new WMDW was less saline and colder than the water detected in HC-ICM in February, which was assumed to be formed in the offshore convection process, can be attributed to a large contribution (i.e. mixing) of cascading waters in the formation of the new 2005 WMDW. This is coherent with the smoother transition in the $\theta$ and $S$ time series in April compared to the abrupt changes in late January and early March (Fig. 4). Presumably, the same phenomenon, with a greater or lesser contribution of cascading waters and LIW/TDW in the WMDW formation mechanism, could have occurred in the past (generating the Variable Bottom Water cited by Lacombe et al., 1985) and could be the explanation for the positive $\theta / \mathrm{S}$ (and turbidity) anomalies formed during the winters of 1971, 1980, 1988 and 1999, which were attributed by Bethoux et al. (2002) solely to the effect of intense dense shelf water cascading events.

\section{CONCLUSIONS}

The time series of data recorded in the deep slope off the Catalan coast, south of the submarine canyons that indent the Gulf of Lions, allowed the sequence of changes experienced by the western Mediterranean deep waters during the exceptional winter 2005 to be documented.

The first sudden transition from the typical WMDW that occupied the deep layer in this area to a saltier and warmer water mass was dated in late January 2005. This has been attributed to the start of the offshore convection process with a contribution of an unusually warm and salty LIW/TDW. Later, a new sudden transition to very dense, fresher and colder water, which lasted for more than one month from late February, has been related to a dominant contribution of very intense and persistent shelf water cascading in the new water mass that reached our deep mooring. The smooth transition towards the final WMDW, observed after spring 2005, resulted from a mixing of the two dense waters generated respectively by offshore convection and shelf cascading.

\section{ACKNOWLEDGEMENTS}

This is a contribution to the CIESM HydroChanges programme and to project MIDAS-4 funded by the Spanish National Programme on Space (ESP2005-06823-C05). The moorings in the submarine canyons were funded by the EuroStrataform project (EU Fifth Framework Programme, EVK3-CT-2002-00079) and the US Office of Naval Research (ONR Grant N00014-041-0379). The deployment and recovery operations for the HC-ICM mooring were done during campaigns on board the B/O García del Cid (MFSTEP project, EU Fifth Framework Programme, EUK32001-00174) and the B/O Cornide de Saavedra 
(TUNIBAL project, Instituto Español de Oceanografía). The authors thank $\mathrm{A}$. Julià for the preparation and on board operations for the HCICM mooring.

\section{REFERENCES}

Astraldi M., F. Conversano, G. Civitarese, G. P. Gasparini, M. Ribera D'Alcalà, and A. Vetrano. - 2002. Water mass properties and chemical signature in the central Mediterranean region. J. Marine Syst., 33-34: 155-177.

Bethoux, J.P., X. Durrieu de Madron, F. Nyffeler, and D. Tailliez. - 2002. Deep water in the western Mediterranean: peculiar 1999 and 2000 characteristics, shelf formation hypothesis, variability since 1970 and geochemical inferences. J. Marine Syst., 33-34: 117-131.

Canals, M., P. Puig, X. Durrieu de Madron, S. Heussner, A. Palanques, and J. Fabrés. - 2006. Flushing submarine canyons, Nature, 444: 354-357, doi:10.1038/nature05271.

CIESM. - 2002. Tracking long-term hydrological change in the Mediterranean Sea. CIESM Workshop Ser., 16, 134 pp., Monaco

Dufau-Julliand, C., P. Marsaleix, A. Petrenko, and I. Dekeyser. 2004. Three-dimensional modeling of the Gulf of Lion's hydrodynamics (northwest Mediterranean) during January 1999 (MOOGLI3 Experiment) and late winter 1999: Western Mediterranean Intermediate Water's (WIW's) formation and its cascading over the shelf break. J. Geophys. Res., 109, C11002.

Durrieu de Madron, X., V. Zervakis, A. Theocharis, and D. Georgopoulos. - 2005. Comments on "Cascades of dense water around the world ocean”. Prog. Oceanogr., 64: 83-90.

Fieux, M. - 1974. Formation d'eau dense sur le plateau du golfe du Lion. In: Processus de formation des eaux profondes. Colloq. Int. CNRS., 215: 165-174.

García-Ladona, E., A. Castellón, J. Font, and J. Tintoré. - 1996. The Balearic current and volume transports in the Balearic basin. Oceanol. Acta, 19: 489-497.

Klein B., W. Roether, B. B. Manca, D. Bregant, V. Beitzel, V. Kovacevic, and A. Luchetta. - 1999. A large deep water transient in the Eastern Mediterranean. Deep-Sea Res. I, 46: 371-414.

Lacombe, H., P. Tchernia, and L. Gamberoni. - 1985. Variable bottom water in the western Mediterranean basin. Prog. Oceanogr., 14: 319-338.
López-Jurado, J.L., C. González-Pola, and P. Vélez-Belchí. - 2005. Observation of an abrupt disruption of the long-term warming trend at the Balearic Sea, western Mediterranean Sea, in summer 2005. Geophys. Res. Lett., 32, L24606, doi: 10.1029/2005GRL024430.

MEDOC group. - 1970. Observation of formation of deep water in the Mediterranean Sea, 1969. Nature, 227: 1037-1040.

Millot, C. - 2005. Circulation in the Mediterranean Sea: Evidences, debates and unanswered questions. Sci. Mar., 69: 5-21.

Millot, C., J. Candela, J.L. Fuda, and Y. Tber. - 2006. Large warming and salinification of the Mediterranean outflow due to changes in its composition. Deep-Sea Res., 53: 656-666

Palanques, A., X. Durrieu de Madron, P. Puig, J. Fabrés, J. Guillén, A. Calafat, S. Heussner, M. Canals, and J. Bonnin. - 2006. Suspended sediment fluxes and transport processes in the Gulf of Lions submarine canyons. The role of storms and dense water cascading. Mar. Geol., 234: 43-61.

Roether, W., B. Manca, B. Klein, D. Bregant, D. Georgopoulos, V. Beitzel, V. Kovacevic, and A. Luchetta. - 1996. Recent changes in Eastern Mediterranean deep waters. Science, 271: 333-335.

Salat J., and J. Font. - 1987. Water mass structure near and offshore the Catalan coast during the winters of 1982 and 1983. Ann. Geophys., 5B: 49-54.

Salat, J., M. Emelianov, and J.L. López-Jurado. - 2006. Unusual extension of Western Mediterranean deep water formation during winter 2005. In: Proc. $5^{a}$ Asamblea Hispano-Portuguesa de Geodesia y Geofísica, Sevilla, Spain (in press).

Schott, F. and K.D. Leaman. - 1991. Observations with Moored Acoustic Doppler Current Profilers in the Convection Regime in the Golfe du Lion. J. Phys. Oceanogr., 21: 558-574.

Schröder, K., G.P. Gasparini, M. Tangherlini, and A. Astraldi. 2006. Deep and intermediate water in the western Mediterranean under the influence of the Eastern Mediterranean Transient. Geophys. Res. Lett., 33, L21607, doi: 10.1029/2006GL027121.

Send, U., J. Font, and C. Mertens. - 1996. Recent observation indicates convection's role in deep water circulation, EOS Trans. $A G U, 77(7)$ : 61-65.

Theocharis, A. and the CIESM initiative group. - 2003. Long-term sustained observing system for climatic variability studies in the Mediterranean. In: Building the European capacity in operational oceanography, Proc. Third Int. Conf. EuroGOOS, Elsevier Oceanography Series, 69: 78-86.

Scient. ed.: M.P. Olivar.

Received January 19, 2007. Accepted March 5, 2007.

Published online May 23, 2007. 